\title{
She Taught Me to See the World (Dedicated to Tatiana Grigoryevna Vladykina)
}

\section{Tatiana Korobova (Okuneva)}

Izhevsk University

It was an ordinary day of study at the University when I first met Tatiana Grigoryevna. She was wearing black clothes and nice glasses. She looked very strict and serious. I do not exactly remember the lecture but I am still impressed by her work with an audience. She was completely absorbed in the theme, her eyes were shining and hands intensely gesturing. Students who were usually talkative and restless were sitting quietly and getting involved in the sacral world of folklore. It seemed that the professor could reach the innermost corners of our souls and reveal genetic layers of traditional consciousness. Culture, rituals, ceremonies, words began to form a certain order and make sense for us.

I could not imagine then that I would be one of those ten lucky people who got their post-graduate degrees in folkloristics under the supervision of Tatiana Grigoryevna. My post-graduate studies began in 2008, since when my way of thinking has changed significantly. Tatiana Grigoryevna taught me to analyse folk materials and read rituals as texts. Moreover, I realised that everything in 
folklore should be found between the lines, and that actions have double meanings. It was difficult and unclear initially, but my tutor was always near and ready to help. She gave me a lot of information and suggested different books and other reading material. We frequently participated in conferences and seminars.

After thirteen years of collaborative work I am proud to say that she has become not only my scientific mentor, but also my friend, my family. She combines such features of character as strictness, fairness, obligation, a sense of humour, responsiveness, kindness and grace in the same way that she combines the roles of elegant woman, perfect homemaker and successful professor.

It is always nice and warm in the house of Tatiana Grigoryevna and Vladimir Yemelyanovich. A special atmosphere of calm, peace and creation prevails there. Books, pictures, souvenirs from all over the world are interspersed with items of traditional Udmurt culture making the home of the professors a place of strength and enrichment. They feed their guests with a delicious dinner and warmly welcome, support, give advice and direction to every person who enters their house.

In my opinion, kindness is the most notable character trait of Tatiana Grigoryevna. She is always ready to help anyone. She finds the answers to all the questions. If she does not find one then she invents something of her own and solves the problem. Each of her graduate students can tell a story about how she helped them in a particular situation.

Tatiana Grigoryevna's love and empathy for animals deserve a mention as a separate topic. This particular trait defines her entire life. Animals always live in her house. Her favourites are cats and dogs. They are treated as family members. Moreover, she feels pity for every homeless animal. One day two years ago, she found a box with six abandoned puppies at a bus stop and could not pass by. Finding a home for puppies required a considerable effort from Tatiana Grigoryevna, but she managed it. Now all the dogs live happily with their new families. 
Undoubtedly, it is impossible to reflect the greatness of Tatiana Grigoryevna's personality in one sketch. You can talk to her and about her endlessly. As her student, I want to express my deep gratitude to her not only for her knowledge and guidance, but also for her inexhaustible interest in life, her endless search for new and unknown things. She taught me to see the world, to look straight and see miracles in everyday life.

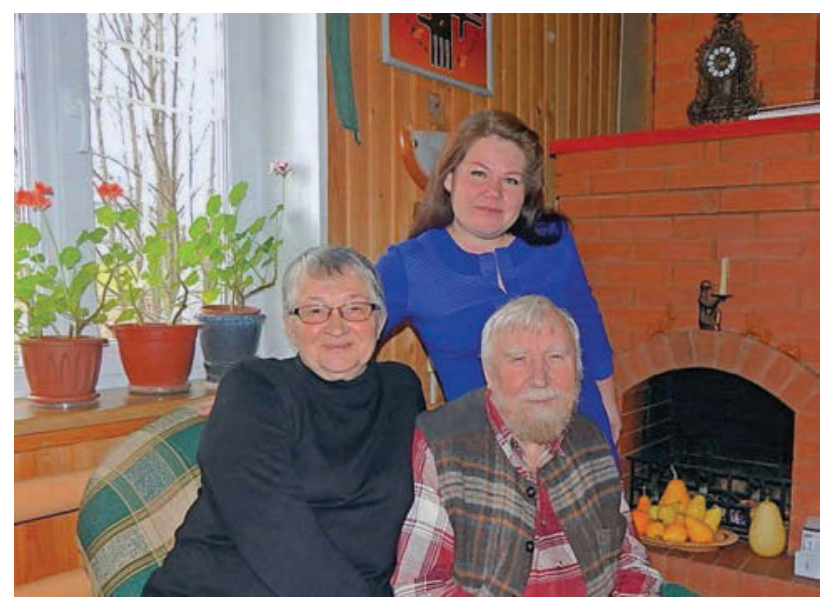

Visiting Vladimir Yemelyanovich and Tatiana Grigoryevna's home. October, 2015. Photo made by E. Okuneva.

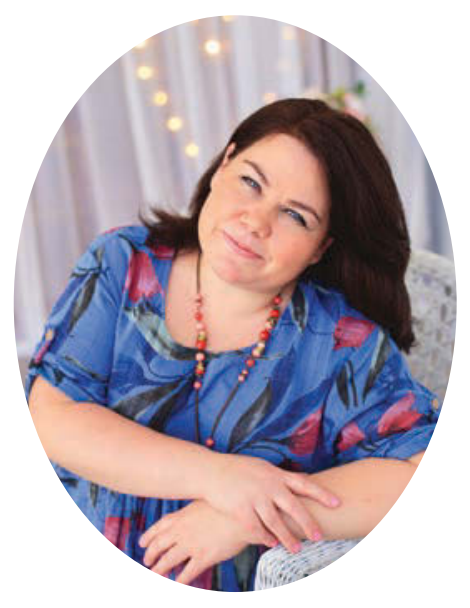

Tatiana Korobova (Okuneva) $(\mathrm{PhD})$ is a folklorist from Izhevsk University. Worked as a researcher at the Department of Philological Studies, at the Udmurt Institute for Research in History, Language and Literature (Ural Branch of the Russian Academy of Sciences). She is interested in Udmurt traditional culture and more precisely in the Udmurt traditional wedding. She currently teaches English at school. e-mail: oktan85@mail.ru 